\title{
Ekstrak Kelopak Rosella Merah (Hibiscus sabdariffa Linn.) Mampu Memperbaiki Histopatologi Hepar Tikus Wistar yang Diberi Paparan Asap Rokok
}

\author{
Arya Ulilalbab ${ }^{1}$, Bambang Wirjadmadi $^{2}$, Merryana Adriani $^{2}$
}

\begin{abstract}
Abstrak
Prevalensi penduduk di Indonesia usia $\geq 15$ tahun yang merokok mengalami peningkatan. Asap rokok merupakan salah satu sumber radikal bebas. Tujuan penelitian ini adalah menganalisis pengaruh ekstrak kelopak rosella merah terhadap degenerasi hepatosit tikus wistar yang diberi paparan asap rokok. Total sampel 20 tikus jantan dan dibagi menjadi empat kelompok: perlakuan ekstrak kelopak rosella merah dosis $540 \mathrm{mg} / \mathrm{bw}$, ekstrak kelopak rosella merah dosis $270 \mathrm{mg} / \mathrm{bw}$, kontrol positif dan kontrol negatif. Kelompok perlakuan diberi pakan standar + ekstrak rosella dipagi hari dan setelah itu dipapar 2 rokok per hari. Kontrol positif diberi pakan standar + dipapar 2 rokok per hari. Kontrol negatif hanya diberi pakan standar. Penelitian dilakukan selama 28 hari. Diakhir penelitian, diamati gambaran histopatologi hepar. Pemberian ekstrak kelopak rosella merah dosis $270 \mathrm{mg} / \mathrm{kg}$ bb dan dosis $540 \mathrm{mg} / \mathrm{kg} \mathrm{bb}$ dapat mencegah degenerasi hepatosit. Analisis degenerasi hepatosit dengan uji Kruskal Wallis pada p<0,05 dan dilakukan uji lanjut Mann-Whitney. Simpulan studi ini ialah semua perlakuan dapat mencegah, bahkan bisa memperbaiki degenerasi hepatosit tikus wistar yang diberi paparan asap rokok.
\end{abstract}

Kata kunci: antioksidan, rosella merah, radikal bebas, asap rokok, degenerasi hepatosit

\section{Abstract}

The population prevalence in Indonesia of aged $\geq 15$ years old who smoke has increased. Cigarette smoke is one of free radical sources. The objective of this study was to analyze the effects of red rosella petal extracts on the degeneration of Wistar rat hepatocytes exposed to cigarette smoke. Total samples of 20 male rats were divided into four groups: the treatment of red rosella petal extract with dose of $540 \mathrm{mg} / \mathrm{bw}$, red rosella petal extract with dose of 270 $\mathrm{mg} / \mathrm{bw}$, positive control and negative control. The treatment group was fed standard + rosella extract in the morning and then, it was exposed to two cigarettes per day. Positive control was fed standard + exposed cigarettes per day. Negative control was only feed standard. This study was conducted for 28 days. At the end of the study, it was analyzed picture of hepatic histopathology. The giving of red rosella petal extract with dose of $270 \mathrm{mg} / \mathrm{kg} \mathrm{bw}$ and a dose of $540 \mathrm{mg} / \mathrm{kg}$ bw can prevent degeneration of hepatocytes. Analysis of degeneration of hepatocytes with Kruskal Wallis test with $p<0.05$ and continued with the Mann-Whitney advanced test. The conclusion is all treatments can prevent, and even can improve Wistar rat hepatocytes degeneration exposed to cigarette smoke.

Keywords: antioxidants, red rosella, free radicals, cigarette smoke, hepatocytes degeneration

Affiliasi penulis: 1. Akademi Gizi Karya Husada Kediri, 2. Program Studi Magister Ilmu Kesehatan Masyarakat Universitas Airlangga. Korespondensi: Arya Ulilalbab. Email: arya17051990@gmail.com, Telp: 085755211490

\section{PENDAHULUAN}

Merokok merupakan hal yang tidak asing dalam kehidupan masyarakat Indonesia. Perilaku merokok penduduk usia $\geq 15$ tahun di Indonesia tahun 
2007 yaitu sebanyak 34,2\%. Dibandingkan dengan hasil Riskesdas 2013 yaitu sejumlah 36,3\%, prevalensi penduduk usia $\geq 15$ tahun yang merokok mengalami peningkatan. ${ }^{1}$

Sulit untuk menghentikan kebiasaan merokok pada masyarakat. Nikotin pada rokok dapat menyebabkan ketagihan dan gangguan pada jantung serta paru - paru. ${ }^{2}$ Radikal bebas sudah terdapat di dalam tubuh (radikal bebas endogenous). Tubuh secara alami juga mempunyai antioksidan yang mampu menghambat oksidasi dengan cara bereaksi dengan radikal bebas reaktif membentuk radikal bebas yang relatif stabil. Apabila radikal bebas terlalu banyak maka antioksidan alami tersebut tidak mampu mengatasinya, sehingga dalam keadaan seperti ini tubuh memerlukan suplai antioksidan. ${ }^{3}$ Contoh sumber antioksidan salah satunya bisa ditemukan pada kelopak rosella. ${ }^{4}$

Berdasarkan Riskesdas 2007 dan 2013, jumlah perokok mengalami peningkatan. ${ }^{5,1}$ Permasalahannya, menghilangkan kebiasaan merokok bukanlah hal yang mudah. Dalam asap rokok terkandung radikal bebas yang membahayakan tubuh, sehingga sementara ini perlu adanya inovasi untuk mengembangkan suatu produk yang dapat meminimalisir dampak negatif yang ditimbulkan oleh rokok. Komponen kimia yang terdapat dalam asap rokok berupa gas danpartikel. ${ }^{6}$ Senyawa gas dan partikel asap rokok beberapa diantaranya bersifat radikal. Walaupun kebanyakan radikal bebas tersebut berumur pendek namun nitritoksida dan radikal quinones dapat mencapai paruparu. ${ }^{7}$ Dari paru - paru, radikal bebas diedarkan menuju jantung dan hepar. ${ }^{8}$ Nekrosis pada sel hepar didasari oleh kerusakan membran sel. ${ }^{9}$ Paparan asap rokok dapat menyebabkan nekrosos sel hepar. ${ }^{10}$ Salah satu organ yang rentan yaitu hepar, karena hepar merupakan filter dari toksik yang masuk ke dalam tubuh. Sistem sirkulasi ganda pada hepar bisa menyebabkan akumulasi toksin di hepar lebih besar. ${ }^{11}$ Radikal bebas dapat menyebabkan perubahan struktur dan fungsi hepar. ${ }^{12}$ Asap rokok kretek dapat menyebabkan terjadinya pengurangan jumlah sel spermatogonium testis tikus wistar. ${ }^{13}$ Sangat ironis, banyak masyarakat yang tidak menyadari akan dampak negative merokok, padahal bahaya merokok sudah tercantum dalam bungkus rokok bahwasanya merokok dapat menyebabkan seseorang menderita penyakit kanker, serangan jantung, impotensi, gangguan kehamilan dan janin. Dampak tersebut berhubungan dengan adanya kandungan radikal bebas dalam asap rokok seperti NO, CO, NOx, $\mathrm{H} 2 \neg \mathrm{O} 2$, aldehid, trace elements dan nitroso compounds. ${ }^{14}$ Radikal bebas dapat menyebabkan stress oksidatif yang merupakan penyebab penyakit degeneratif. Alternatif yang akan ditawarkan yaitu pemanfaatan ekstrak kelopak rosella dalam pelarut air. Hal ini dikarenakan ekstrak rosella dalam pelarut air selanjutnya dapat diaplikasikan untuk bahan tambahan pangan fungsional. Pelarut air cocok untuk mengekstrak antosianin yang mempunyai kepolaran sama dengan air. Pelarut air dipilih karena lebih aman dan mudah diaplikasikan dalam skala rumah tangga. Ekstraksi kelopak rosella dengan menggunakan pelarut air mempunyai total aktivitas antioksidan paling tinggi dibandingkan biji, daun, maupun batang rosella. ${ }^{4}$ Kelopak rosella dalam pelarut air mempunyai total aktivitas antioksidan yang tinggi yaitu sebesar $54,1 \%{ }^{4}$ Rosella banyak mengandung antosianin dimana satu gram rosella mengandung $56,5 \mathrm{mg}$ delphinidin-3-Osambubioside dan 20,8 mg cyanidin-3-Osambubioside. ${ }^{15}$ Antioksidan dan metabolisme obat yang berasal dari ekstrak antosianin rosella berpotensi mengatasi kerusakan oksidatif pada hati tikus yang diinduksi $\mathrm{CCl} 4 .^{16}$

Radikal bebas dapat dinetralisir oleh antioksidan dengan cara menerima atau mendonorkan sebuah elektron untuk menghasilkan molekul yang lebih stabil. Radikal bebas bisa bersumber dari asap kendaraan bermotor, minyak jelantah dan asap rokok. Asap rokok mempunyai kandungan radikal bebas dengan konsentrasiyang tinggi. ${ }^{17}$ Antioksidan yang terkandung dalam effervescent rosella ungu terbukti efektif menangkal radikal bebas yang bersumber dari minyak jelantah. ${ }^{18}$

Perlu pengkajian lebih lanjut apakah antioksidan ekstrak rosella dapat menangkal radikal bebas yang bersumber dari paparan asap rokok. Sejauh ini belum diketahui pengaruh antioksidan pada ekstrak kelopak rosella merah dalam kemampuannya untuk menangkal radikal bebas yang bersumber dari 
asap rokok. Kelopak rosella dipilih karena kandungan antosianin paling tinggi dibandingkan bagian lain dari tanaman tersebut.

Berdasarkan hal diatas, perlu dilakukan penelitian tentang manfaat ekstrak kelopak rosella melalui pengujian pada hewan coba yang diberi paparan asap rokok dengan melihat indikator stres oksidatif berupa degenerasi hepatosit. Tujuan penelitian ini yaitu untuk mengetahui pengaruh pemberian ekstrak rosella merah terhadap degenerasi hepatosit tikus wistar yang diberi paparan asap rokok.

\section{METODE}

Jenis penelitian ini yaitu eksperimental laboratorium. Tahap in-vivo yang digunakan adalah true experimental laboratory dengan desain pengambilan secara post test pada kelompok perlakuan, kelompok kontrol positif dan kontrol negatif. Rancangan perlakuan pada penelitian ini yaitu Rancangan Acak Lengkap.

Jumlah tikus yang digunakan sebanyak 20 ekor, berkelamin jantan dipilih dengan cara random sampling untuk dibagi dalam satu kelompok kontrol negatif (normal), satu kelompok kontrol positif, dan dua kelompok perlakuan. Setiap kelompok terdiri dari 5 ekor tikus dengan penjelasan sebagai berikut:

1. Kelompok I adalah kontrol negatif (kelompok normal) diberi pakan standar, tidak diberi ekstrak rosella dan tidak diberi paparan asap rokok.

2. Kelompok II adalah kontrol positif: diberi pakan standard, diberi air $1 \mathrm{ml}$ p.o (per-oral) selanjutnya diberi paparan asap rokok sebanyak 2 batang.

3. Kelompok $\mathrm{V}$ adalah perlakuan 3: diberi pakan standar, diberi ekstrak rosella merah dosis $270 \mathrm{mg} / \mathrm{kg}$ BB p.o selanjutnya diberi paparan asap rokok sebanyak 2 batang.

4. Kelompok VI adalah perlakuan 4: diberi pakan standar, diberi ekstrak rosella merah dosis $540 \mathrm{mg} / \mathrm{kg}$ BB p.o selanjutnya diberi paparan asap rokok sebanyak 2 batang. Tahap in-vivo dilakukan dengan memberikan ekstrak rosella merah sesuai dosis yang telah ditetapkan. Tahap lainnya meliputi paparan asap rokok selama 28 hari. Pada tahap akhir dilakukan pengujian bio-assay terhadap degenerasi hepatosit. Pakan hewan coba memakai merk POKPHAND CP 591 , dengan komposisi protein 18,0-20,0\%, kadar air $\max 13,0 \%$, abu max $7,0 \%$, serat $\max 6,0 \%$, lemak $\min 3,0 \%$, kalsium min $0,9 \%$, dan phosphor min $0,6 \%$. Bahan yang dipakai dalam formulasi pakan antara lain dedak, jagung, tepung ikan, bungkil kelapa, bungkil kedelai, bungkil kacang tanah, tepung daging dan tulang, tepung daun, pecahan gandum, canola, kalsium, fosfat, vitamin dan trace mineral. Rokok yang digunakan dalam penelitian ini mengandungan nikotin 2,1 $\mathrm{mg}$ dan tar sebesar $34 \mathrm{mg}$. Dosis paparan asap rokok sebanyak 2 batang/tikus/hari. Pemaparan dilaksanakan setelah pemberian ekstrak rosella p.o pada kelompok perlakuan. Pemaparan dilaksanakan pada kelompok perlakuan dan kelompok kontrol positif. Penelitian telah dilaksanakan selama 6 bulan dan dilakukan di beberapa tempat, yaitu: laboratorium In Vivo FK Universitas Wijaya Kusuma Surabaya, laboratorium Pengujian Mutu dan Keamanan Pangan Universitas Brawijaya, laboratorium Farmakologi FK Universitas Brawijaya, laboratorium Patologi Anatomi FK Universitas Airlangga dan laboratorium Patologi Anatomi GDC RSUD dr. Soetomo Surabaya. Analisa data sampel pada penelitian ini menggunakan tikus putih jantan dewasa usia 3-4 bulan jenis Rattus norvegicus strain Wistar dengan berat rerata 180-200 gram. Lima ekor tikus ditempatkan pada masingmasing kelompok. Pada tahap awal akan dilakukan analisis normalitas dengan uji Shapiro-Wilk dan uji homogenitas dengan Levene Statistic. Data tidak homogen, sehingga dilakukan pengujian nonparametrik dengan Kruskal Wallis dan untuk melihat perbedaaan tiap kelompok maka digunakan uji MannWhitney.

\section{HASIL}

Gambaran Histopatologi Hepar area Vena Sentral

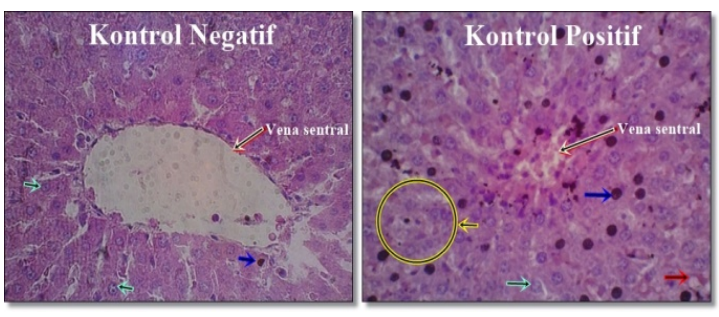

Gambar 1. Histologi hepar tikus wistar dengan pengecatan HE pada kelompok kontrol negatif (kiri) dan kelompok kontrol positif (kanan) pada perbesaran 400x. 
Pada kelompok kontrol negatif/normal sedikit sel yang mengalami piknosis, sel secara umum masih dalam kondisi normal (tanda panah biru muda). Sedangkan pada kelompok kontrol positif menunjukkan kerusakan yang bersifat irreversibel. Adanya bagian yang mengalami karyolisis (tanda panah kuning), ada sel yang mengalami hydrophic degeneration (tanda panah merah) dan banyaknya sel yang mengalami piknosis (tanda panah biru tua).
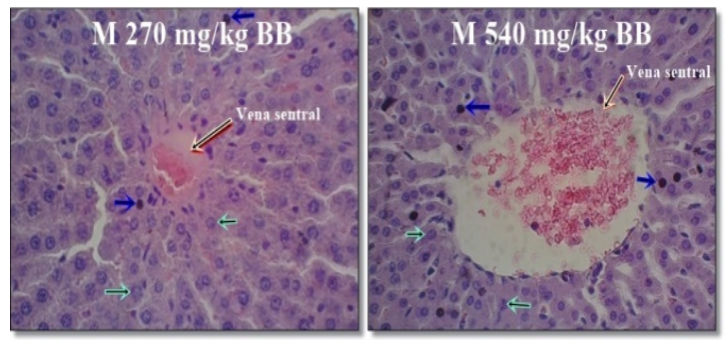

Gambar 2. Histologi hepar tikus wistar dengan pengecatan HE pada kelompok perlakuan pemberian ekstrak rosella merah dosis $270 \mathrm{mg} / \mathrm{kg}$ bb (kiri) dan dosis $540 \mathrm{mg} / \mathrm{kg}$ bb (kanan) pada perbesaran 400x.

Kelompok ekstrak kelopak rosella merah dosis $270 \mathrm{mg} / \mathrm{kg} \mathrm{BB}$ dan $540 \mathrm{mg} / \mathrm{kg} \mathrm{BB}$, sel piknosis (tanda panah biru tua) lebih sedikit dibandingkan kontrol positif. Kondisi sel secara umum masih normal (tanda panah biru muda). Pada pemberian dosis $270 \mathrm{mg} / \mathrm{kg}$ BB (rerata degenerasi 22,40) dan dosis $540 \mathrm{mg} / \mathrm{kg} \mathrm{BB}$ (rerata degenerasi 16,75) mengalami kerusakan sangat ringan, bahkan lebih baik dibandingkan kelompok kontrol negatif (rerata degenerasi 46,20).

\section{Gambaran Histopatologi Hepar area Tepi Hepar}
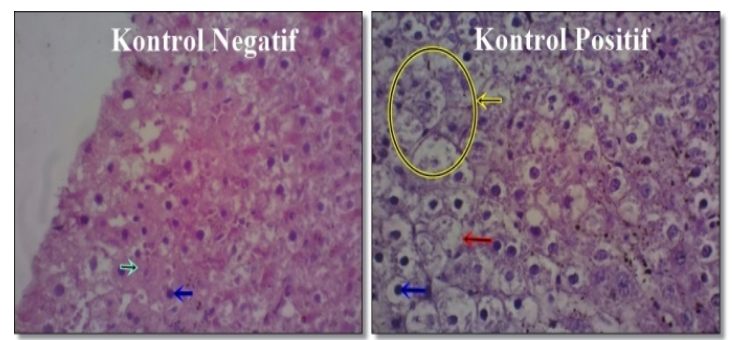

Gambar 3. Histologi bagian tepi hepar tikus wistar dengan pengecatan HE pada kelompok kontrol negatif (kiri) dan kelompok kontrol positif (kanan) pada perbesaran $400 x$

Pada kelompok kontrol negatif, sel yang mengalami piknosis (tanda panah biru tua) jumlahnya lebih sedikit dibandingkan kelompok kontrol positif sehingga secara umum masih dalam kondisi normal (tanda panah biru muda). Pada kelompok kontrol positif menunjukkan kerusakan berat. Hal ini ditandai dengan adanya karyolisis (tanda panah kuning) dan banyaknya sel yang mengalami hydrophic degeneration (tanda panah merah) dan yang mengalami piknosis (tanda panah biru tua).
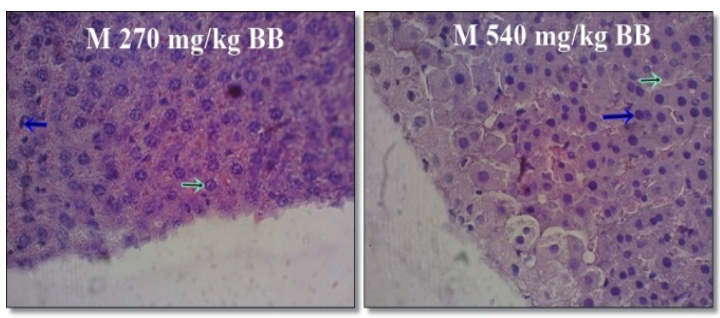

Gambar 4. Histologi bagian tepi hepar tikus wistar dengan pengecatan HE pada kelompok perlakuan pemberian ekstrak rosella merah dosis $270 \mathrm{mg} / \mathrm{kg} \mathrm{bb}$ (kiri) dan dosis $540 \mathrm{mg} / \mathrm{kg}$ bb (kanan) pada perbesaran 400x.

Kelompok ekstrak kelopak rosella merah dosis $270 \mathrm{mg} / \mathrm{kg}$ BB dan $540 \mathrm{mg} / \mathrm{kg} \mathrm{BB}$, sel yang mengalami hydrophic degeneration jumlahnya sangat sedikit dibandingkan yang terdapat pada kontrol positif.

\section{PEMBAHASAN}

Rerata degenerasi hepatosit pada ekstrak rosella merah dosis $540 \mathrm{mg} / \mathrm{kg}$ bb adalah 24,2, ekstrak rosella merah dosis $270 \mathrm{mg} / \mathrm{kg}$ bb adalah 48 , kelompok kontrol positif adalah 118, dan kelompok kontrol negatif adalah 46,2. Kelompok pemberian ekstrak rosella merah dosis $540 \mathrm{mg} / \mathrm{kg}$ bb mempunyai degenerasi hepatosit paling rendah karena diberi perlakuan pemberian ekstrak p.o dimana ekstrak yang diberikan pada kelompok tersebut mempunyai aktivitas antioksidan paling tinggi dibandingkan kelompok perlakuan lain. Sebaliknya, pada kontrol positif jumlah sel hepar yang mengalami degenerasi paling banyak karena pada kontrol positif hewan coba diberi paparan asap rokok saja tanpa adanya asupan antioksidan.

Kelompok perlakuan ekstrak rosella merah dosis $540 \mathrm{mg} / \mathrm{kg}$ bb signifikan dengan semua kelompok. Hal ini menandakan bahwa pemberian 
ekstrak rosella merah dosis $540 \mathrm{mg} / \mathrm{kg}$ bb memberikan pengaruh nyata terhadap pencegahan dan penurunan stres oksidatif yang ditimbulkan oleh asap rokok.Rosella merah dosis $270 \mathrm{mg} / \mathrm{kg}$ bb tidak signifikan dengan kelompok negatif, sehingga dapat disimpulkan bahwa kelompok ekstrak rosella merah dosis $270 \mathrm{mg} / \mathrm{kg}$ bb mampu menyamai kondisi normal walaupun diberi perlakuan paparan asap rokok. Hal ini menindikasikan bahwa rosella merah dosis $270 \mathrm{mg} / \mathrm{kg}$ bb mampu mencegah degenerasi hepatosit.

Pada kelompok kontrol positif menunjukkan jumlah degenerasi hepatosit yang lebih banyak dibandingkan kelompok perlakuan ataupun kelompok kontrol negatif. Hal ini dikarenakan asap rokok mengandung radikal bebas tar ataupun komponen gas. ${ }^{10}$ Asap rokok mengandung radikal bebas dan radikal bebas tersebut masuk melalui saluran nafas menuju paru - paru, kemudian terikut aliran darah dan bisa sampai hepar. ${ }^{8}$ Radikal bebas ini disebabkan oleh adanya komponen tar yang ada pada asap rokok. Pembentukan radikal peroksil dan hidrogen peroksida dikatalisa oleh ion besi yang berasal dari komponen tar. ${ }^{19}$ Ion besi dan protein feritin yang dilepaskan oleh semiquinon dan hidroquinon pada tar juga bisa menyebabkan lebih banyak ion besi yang bebas. ${ }^{20}$

\section{SIMPULAN}

Semua kelompok perlakuan pemberian ekstrak kelopak rosella merah mampu mencegah degenerasi hepatosit tikus wistar yang diberi paparan asap rokok. Bahkan pada kelompok perlakuan pemberian ekstrak rosella merah dosis $540 \mathrm{mg} / \mathrm{kg}$ bb mampu mencegah degenerasi hepatosit secara optimal. Hal ini ditandai dengan lebih sedikitnya degenerasi hepatosit pada perlakuan tersebut dibandingkan kontrol negatif (normal).

\section{DAFTAR PUSTAKA}

1. Badan Penelitian dan Pengembangan Kesehatan Kementerian Kesehatan RI. Riset kesehatan dasar (Riskesdas) 2013. Jakarta; 2013. Tersedia dari: URL: HYPERLINK http://www.litbang.depkes.go.id/ sites/download/rkd2013/Laporan Riskesdas2013. PDF
2. Voges E. Tobacco encyclopedia. Tabac Journal International, Mainz, Germany. 2000; 279p.

3. Sofia D. Antioksidan dan radikal bebas. 2006. Tersedia dari: URL: HYPERLINK http://www.chemistry.org

4. Esa NM, Hern FS, Ismail A, Yee CL. Antioxidant activity in different parts of roselle (Hibiscus sabdariffa L.) extracts and potential exploitation of the seeds. Food Chemistry. 2010;122:1055-60.

5. Badan Penelitian dan Pengembangan Kesehatan Kementerian Kesehatan RI. Riset kesehatan dasar (Riskesdas) 2007. Jakarta; 2007. Tersedia dari: URL: HYPERLINK http://www.litbang.depkes.go.id/ bl riskesdas2007/

6. Tirtosastro S, Murdiyati AS. Kandungan kimia tembakau dan rokok. Buletin Tanaman Tembakau, Serat dan Minyak Industri. 2010;2(1):33-43.

7. Subandi. Efek antioksidan (Vit. C) terhadap jumlah fungsi makrofag alveoli serta kadar SOD jaringan paru tikus yang dipapar dengan asap rokok kronis (tesis). Malang: Universitas Brawijaya; 1999.

8. Guyton AC, Hall JE. Buku ajar fisiologi kedokteran (terjemahan). Edisi ke-9. EGC: Jakarta; 1997.

9. Lu, Frank C. Toksikologi dasar. Universitas Indonesia Press: Jakarta; 1995.

10. Muliartha IKG, Sriwahyuni E, Yuliawati. Pemberian kombinasi vitamin $\mathrm{C}$ dan $\mathrm{E}$ peroral memperbaiki kerusakan hepar akibat paparan rokok kretek sub kronik. Jurnal Kedokteran Brawijaya. 2009;24(1): 23-7.

11. Ganong WF. Fisiologi kedokteran (terjemahan). EGC: Jakarta; 1980.

12. Cassarett $L$. The basic science of poisons. USA: McGraw-Hill Inc; 1993.

13. Kurnia H, Permatasari N, Subandi. Pengaruh ekstrak jintan hitam terhadap MDA dan sel spermatogonium tikus yang dipapar asap rokok kretek subakut. Jurnal Kedokteran Brawijaya. 2011;26(3):161-5.

14. Valvanidis A, Haralambous E. A comparative study by electron paramagnetic resonance of free radicals species in the main steam and side stream smoke of cigarettes with conventional aceate filters and biofilters. Redox Report. 2001;(6):161-71. 
15. Alarco-Alanso J, Zamilpa A, Aguilar FA, HerreraRuiz M, Tortoriello J, Jimenez-Ferrer E. Pharmacological characterization of the diuretic effect of Hibiscus sabdariffa Linn (Malvaceae) extract. J Ethnopharmacol. 2012;139(6):751.

16. Ajiboye TO, Salawu NA, Yakubu MT, Oladiji AT, Akanji MA, Okogun JI. Antioxidant and drug detoxification potentials of Hibiscus sabdariffa anthocyanin extract. Drug Chem Toxicol. 2011;34: 109-15.

17. Park EM, Park TM, Gwak YS. Oxidative damaged tissue of rats exposed to cigarette smoke. Free Radicals Biology Medicine. 1998;25(1):79-86.
18. Ulilalbab A, Priyanto AD, Maulana HI, Fitriani E, Resti F, Estiasih T. Pemberian tablet effervescent rosella ungu menurunkan nilai MDA (Malondialdehid) tikus wistar yang dipapar minyak jelantah. The Indonesian Journal of Public Health. 2012;9(1):81-6.

19. Halliwel B, Gutteridge J. Free radicals in biology and medicine Edisi ke-3. New York: Oxford University Press. 1999.

20. Halliwel B, Gutteridge J. Antioxidant in nutrition, health, and disease. New York: Oxford University Press Inc;1996. 